\title{
PERILAKU HIDUP BERSIH DAN SEHAT MAHASISWA UNIVERSITAS MAHASARASWATI DENPASAR SELAMA PANDEMI COVID-19
}

\author{
(CLEAN AND HEALTHY LIVING BEHAVIORS OF UNVERSITAS MAHASARASWAWATI \\ DENPASAR'S COLLEGE STUDENTS DURING THE COVID-19 PANDEMIC)
}

\author{
NI PUTU UDAYANA ANTARI ${ }^{1 \bullet}$, NI PUTU KURNIA DEWI ${ }^{1}$, KADEK AYU KARTIKA PUTRI $^{1}$, \\ LUH RISMA PUTRI RAHAYU ${ }^{1}$, NI PUTU NADYA KIRANA WULANDARI ${ }^{1}$, \\ NI PUTU WULAN NINGSIH ${ }^{1}$, NI WAYAN ARI PERTIWI ${ }^{1}$, \\ NI PUTU SRI DEVI CHYNTA CAHYANTI ${ }^{1}$, MADE ELVENIA MABARA DAMAYANTI ${ }^{1}$, \\ MADE TARYSA LAKSMI DEWI ${ }^{1}$, KOMANG TRI CANDRAYANI $^{1}$, \\ GUSTI BAGUS KRISNA ARUM JATI ${ }^{1}$ \\ ${ }^{1}$ Program Studi Sarjana Farmasi, Fakultas Farmasi, Universitas Mahasaraswati Denpasar
}

\begin{abstract}
Abstrak: COVID-19 menjadi wabah yang telah menyebar luas di dunia termasuk Indonesia. Perilaku Hidup Bersih dan Sehat atau PHBS adalah upaya untuk memperkuat budaya seseorang, kelompok maupun masyarakat agar peduli dan mengutamakan kesehatan untuk mewujudkan kehidupan yang lebih berkualitas. Mahasiswa di fakultas kesehatan memiliki akses yang lebih banyak terhadap informasi kesehatan dibandingkan fakultas non kesehatan. Penerapan PHBS dengan baik dapat membantu pencegahan COVID-19. Oleh karena itu, penelitian dilaksanakan untuk mengetahui perbedaan perilaku hidup bersih dan sehat antara mahasiswa fakultas kesehatan dan mahasiswa fakultas nonkesehatan di Universitas Mahasaraswati Denpasar. Penelitian dilaksanakan menggunakan 96 orang responden yang telah memenuhi kriteria inklusi dan eksklusi. Responden dibagi menjadi dua kelompok yaitu 48 orang mahasiswa fakultas kesehatan dan 48 orang mahasiswa fakultas non kesehatan. Hasil uji Mann-Whitney menunjukkan bahwa tidak ada perbedaan yang signifikan mengenai perilaku hidup bersih dan sehat antara mahasiswa fakultas kesehatan dan fakultas nonkesehatan $(\mathrm{P}=0,403)$. Dengan demikian dapat ditarik kesimpulan bahwa latar belakang pendidikan tinggi tidak mempengaruhi perilaku PHBS mahasiswa di Universitas Mahasaraswati Denpasar.
\end{abstract}

Kata Kunci: COVID-19, PHBS, virus corona

\begin{abstract}
COVID-19 is an epidemic that has spread widely in the world, including Indonesia. Clean and Healthy Living Behavior or PHBS is an effort to strengthen the culture of a person, group and community to care for and prioritize health to create a higher quality life. Students in the health faculty have more access to health information than non-health faculties. Proper implementation of PHBS can help prevent COVID-19. Therefore, the research was conducted to determine the differences in hygiene and healthy living habits between health faculty students and non-health faculty students at Mahasaraswati University Denpasar. The study was conducted using 96 respondents who had met the inclusion and exclusion criteria. Respondents were divided into two groups, namely 48 health faculty students and 48 non-health faculty students. The results of the Mann-Whitney test showed that there was no significant difference regarding hygiene and healthy living behavior between health and non-health faculty students $(\mathrm{P}=0.403)$. Thus it can be concluded that the higher education background does not affect the PHBS behavior of students at Universitas Mahasaraswati Denpasar. Keywords: coronavirus, COVID-19, PHBS
\end{abstract}

\section{PENDAHULUAN}

Merebaknya coronavirus jenis baru (SARS-CoV-2) yang penyakitnya disebut Coronavirus disease 2019 (COVID-19) menimbulkan pengaruh yang sangat besar bagi kehidupan masyarakat. Diketahui bahwa virus ini berasal dari Wuhan, Tiongkok yang ditemukan pada akhir Desember tahun 2019 (Yuliana, 2020). Menurut data dari World Health Organization
(2020), hingga tanggal 24 Mei 2020 telah ditemukan sebanyak 5.206.614 kasus yang terkonfirmasi. Ada bermacam-macam gejala yang bisa ditimbulkan dari orang yang terinfeksi virus corona, mulai dari gejala ringan, gejala sedang, hingga gejala berat. Gejala yang umumnya muncul pada orang yang terinfeksi virus corona adalah demam (suhu tubuh $>38^{\circ} \mathrm{C}$ ), batuk, dan kesulitan bernapas. Saat masuk ke dalam tubuh, genom RNA virus akan dikeluarkan ke sitoplasma sel dan

• email korespondensi: putuudayana87@gmail.com 
ditranslasikan menjadi dua polyprotein dan protein struktural. Selanjutnya, genom virus akan mulai bereplikasi. Kemudian partikel virus akan tumbuh di dalam retikulum endoplasma dan golgi sel. Pada tahap akhir, vesikel yang mengandung partikel virus akan bergabung dengan membran plasma untuk melepaskan komponen virus baru (Susilo, dkk, 2020). Dikutip dari World Health Organization (2020), virus corona dapat menyebar dari tetesan atau percikan kecil dari hidung atau mulut orang yang terinfeksi virus tersebut. Virus ini juga dapat menyebar melalui benda-benda yang di sentuh oleh orang yang terinfeksi virus corona. Maka dari itu, kita dianjurkan untuk selalu menggunakan masker untuk mencegah mulut dan hidung dari percikan penderita dan selalu mencuci tangan agar virus tidak menempel di tubuh kita.

Perilaku Hidup Bersih dan Sehat (PHBS) adalah semua perilaku yang dilakukan atas kesadaran sehingga anggota keluarga atau keluarga dapat menolong dirinya sendiri di bidang kesehatan dan berperan aktif dalam kegiatankegiatan kesehatan di masyarakat. Mencegah lebih baik daripada mengobati, prinsip kesehatan inilah yang menjadi dasar pelaksanaan program PHBS. Tujuan utama dari gerakan PHBS adalah meningkatkan kualitas kesehatan melalui proses menyadarkan masyarakat dengan pengetahuan yang menjadi awal dari kontribusi individu dalam menjalani perilaku kehidupan sehari-hari yang bersih dan sehat. Manfaat PHBS yang paling utama adalah terciptanya masyarakat yang sadar kesehatan dan memiliki bekal pengetahuan dan kesadaran untuk menjalani perilaku hidup dengan menjaga kebersihan yang memenuhi standar kesehatan (Kemenkes RI, 2016).

Perilaku Hidup Bersih dan Sehat (PHBS) berkaitan erat dengan pencegahan penyebaran COVID-19. Beberapa cara mencegah risiko terinfeksi COVID-19, yaitu dengan mencuci tangan menggunakan air dan sabun atau gunakan cairan pembersih tangan (minimal 70\% alkohol), mencuci tangan merupakan salah satu indikator PHBS. Selain itu protokol yang harus dilaksanakan antara lain menggunakan masker bila bepergian, jaga jarak minimal 1 meter dengan orang lain, tutup mulut dan hidung dengan siku terlipat saat batuk atau bersin atau gunakan tisu, hindari menyentuh wajah karena mulut, hidung, mata dapat menjadi pintu masuk virus, bersihkan benda, permukaan, dan alat-alat yang sering digunakan, khususnya yang berada atau digunakan secara umum, mengkonsumsi makanan bergizi seimbang, tidak merokok, istirahat secara teratur, berolahraga serta berpikir positif. Selalu pantau perkembangan penyakit COVID-19 dari sumber resmi dan akurat.
Ikuti arahan dan informasi dari petugas kesehatan dan Dinas Kesehatan setempat (Kemenkes RI, 2020). Menurut Roy et al (2020) Responden tenaga kesehatan memiliki tingkat kesadaran tinggi mengenai mode penyebaran, gejala, dan kesadaran yang memadai tentang pencegahan COVID-19. Hal ini disebabkan karena pemerintah dan media lebih menekankan pada langkah-langkah pencegahan. Selain itu tenaga kesehatan diberikan pendidikan sehingga lebih peka terhadap pengetahuan COVID-19. Penelitian ini bertujuan untuk menilai perbedaan perilaku Mahasiswa Fakultas Kesehatan dan Fakultas Non Kesehatan Universitas Mahasaraswati Denpasar dalam situasi pandemi COVID-19.

\section{METODE PENELITIAN}

Rancangan Penelitian. Data penelitian diambil secara cross sectional dan diolah menggunakan metode analitik dengan membandingkan perilaku antar kelompok.

Populasi dan Sampel. Populasi dalam penelitian ini adalah seluruh mahasiswa di Universitas Mahasaraswati Denpasar. Sampel pada penelitian ini adalah mahasiswa kesehatan yang meliputi mahasiswa Fakultas Farmasi dan Fakultas Kedokteran Gigi serta mahasiswa nonkesehatan yang meliputi mahasiswa Fakultas Ekonomi dan Bisnis, Fakultas Keguruan dan Ilmu Pendidikan, Fakultas Bahasa Asing, Fakultas Hukum, Fakultas Teknik dan Fakultas Pertanian. Jumlah sampel dalam penelitian ini dihitung menurut rumus Slovin (Sevilla et al., 1960) sebagai berikut:

Keterangan:

$$
\mathrm{n}=\frac{N}{1+\left(N \cdot e^{2}\right)}
$$

n : jumlah sampel minimal

$\mathrm{N} \quad$ : jumlah populasi (Kesehatan: 1.314 dan

Non-kesehatan: 12.993)

e $\quad$ : tingkat kesalahan $15 \%(0,15)$

Menurut perhitungan diatas, sampel minimal untuk mahasiswa fakultas kesehatan yaitu 43 sehingga dalam penelitian ini diambil 48 orang responden mahasiswa fakultas kesehatan sedangkan sampel minimal untuk mahasiswa fakultas nonkesehatan yaitu 44 sehingga dalam penelitian ini diambil 48 orang responden mahasiswa fakultas nonkesehatan.

Instrumen Penelitian. Penelitian ini dilakukan dengan menyebarkan kuesioner online melalui google form dirancang dalam bentuk pertanyaan dan jawaban tertutup. Kuesioner yang dirancang memuat pertanyaan mengenai perilaku hidup bersih dan sehat dan dari setiap pertanyaan tersebut dirancang pertanyaan dengan jawaban mendukung 
(favorable) dan jawaban yang tidak mendukung (unfavorable). Penilaian untuk kuesioner mengenai perilaku hidup bersih dan sehat dilakukan dengan memberi poin "1" jika responden menunjukkan perilaku positif dan poin "0" jika responden menunjukkan perilaku negatif.

1. Kriteria Inklusi

Mahasiswa Universitas Mahasaraswati Denpasar yang memiliki KTM

2. Kriteria Eksklusi

a. Mahasiswa yang tidak bersedia mengisi kuesioner

b. Mahasiswa yang tidak menyelesaikan kuesioner dengan lengkap

Pengambilan dan Analisis Data. Pengambilan data dilakukan dengan menyebarkan kuesioner online melalui google form pada total 96 responden (48 responden mahasiswa fakultas kesehatan dan 48 responden mahasiswa fakultas nonkesehatan) yang telah memenuhi kriteria inklusi dan eksklusi. Data yang telah diperoleh selanjutnya dianalisis dengan mencari total skor dari nilai yang telah diperoleh di setiap kuesioner. Untuk mencari perbedaan PHBS pada fakultas kesehatan dan nonkesehatan digunakan uji Mann-Whitney. Hubungan antara jenis kelamin dan usia dengan skor mahasiswa juga diuji menggunakan uji Korelasi Pearson.

\section{HASIL DAN PEMBAHASAN}

Penelitian ini berfokus pada Perilaku Hidup Bersih dan Sehat (PHBS) yang ditujukan kepada Mahasiswa Universitas Mahasaraswati Denpasar dalam situasi pandemi COVID-19. Dalam penelitian ini, responden terdiri atas mahasiswa yang berasal dari fakultas kesehatan yang meliputi Fakultas Farmasi yaitu sebanyak 24 responden dan Fakultas Kedokteran Gigi sebanyak 24 responden. Pada fakultas nonkesehatan meliputi Fakultas Ekonomi dan Bisnis, Fakultas Keguruan dan Ilmu Pendidikan, Fakultas Hukum, Fakultas Teknik, Fakultas Pertanian serta Fakultas Bahasa Asing.

Tabel 1. Distribusi Responden Mahasiswa Fakultas Kesehatan dan Mahasiswa Fakultas Nonkesehatan di Universitas Mahasaraswati Denpasar

\begin{tabular}{cccc}
\hline $\begin{array}{c}\text { Karak- } \\
\text { teristik }\end{array}$ & Fakultas & $\begin{array}{c}\text { Jum- } \\
\text { lah }\end{array}$ & $\begin{array}{c}\text { Persen- } \\
\text { tase (\%) }\end{array}$ \\
\hline Fakultas & $\begin{array}{c}\text { Fakultas } \\
\text { Farmasi }\end{array}$ & 24 & $25 \%$ \\
Kesehatan & $\begin{array}{c}\text { Fakultas } \\
\text { Kedokteran } \\
\text { Gigi }\end{array}$ & 24 & $25 \%$ \\
& & & \\
\hline
\end{tabular}

\begin{tabular}{|c|c|c|c|}
\hline $\begin{array}{l}\text { Karak- } \\
\text { teristik }\end{array}$ & Fakultas & $\begin{array}{c}\text { Jum- } \\
\text { lah }\end{array}$ & $\begin{array}{l}\text { Persen- } \\
\text { tase }(\%)\end{array}$ \\
\hline \multirow[t]{5}{*}{ Total } & & 48 & $50 \%$ \\
\hline & Fakultas & & \\
\hline & $\begin{array}{c}\text { Ekonomi dan } \\
\text { Bisnis }\end{array}$ & 8 & $8,33 \%$ \\
\hline & Fakultas & & \\
\hline & $\begin{array}{c}\text { Keguruan dan } \\
\text { Ilmu }\end{array}$ & 8 & $8,33 \%$ \\
\hline \multirow{6}{*}{$\begin{array}{l}\text { Fakultas } \\
\text { Non } \\
\text { kesehatan }\end{array}$} & Pendidikan & & \\
\hline & $\begin{array}{l}\text { Fakultas } \\
\text { Hukum }\end{array}$ & 8 & $8,33 \%$ \\
\hline & Fakultas & 8 & $8,33 \%$ \\
\hline & $\begin{array}{c}\text { Teknik } \\
\text { Eakultas }\end{array}$ & & \\
\hline & Pertanian & 8 & $8,33 \%$ \\
\hline & $\begin{array}{c}\text { Fakultas } \\
\text { Bahasa Asing }\end{array}$ & 8 & $8,33 \%$ \\
\hline Total & & 48 & $\mathbf{5 0 \%}$ \\
\hline
\end{tabular}

Tabel 2. Distribusi Responden Jenis Kelamin dan Usia

\begin{tabular}{|c|c|c|c|}
\hline \multicolumn{2}{|c|}{ Karakteristik } & \multirow{2}{*}{$\begin{array}{c}\text { Jumlah } \\
27\end{array}$} & \multirow{2}{*}{$\begin{array}{c}\text { Persentas } \\
28,1 \%\end{array}$} \\
\hline Jenis & Laki-laki & & \\
\hline Kelamin & Perempuan & 69 & $71,9 \%$ \\
\hline \multicolumn{2}{|c|}{ Total } & 96 & $100 \%$ \\
\hline \multirow{7}{*}{ Usia } & 18 & 20 & $19,56 \%$ \\
\hline & 19 & 56 & $59,78 \%$ \\
\hline & 20 & 11 & $11,96 \%$ \\
\hline & 21 & 5 & $4,35 \%$ \\
\hline & 22 & 3 & $3,26 \%$ \\
\hline & 23 & - & - \\
\hline & 24 & 1 & $1,09 \%$ \\
\hline \multicolumn{2}{|c|}{ Total } & 96 & $100 \%$ \\
\hline
\end{tabular}

Tabel 3. Distribusi Responden Berdasarkan Total Perilaku Positif

\begin{tabular}{ccc}
\hline Karakteristik & $\begin{array}{c}\text { Total } \\
\text { Perilaku } \\
\text { Positif }\end{array}$ & $\begin{array}{c}\text { Persentase } \\
(\mathbf{\%})\end{array}$ \\
\hline $\begin{array}{c}\text { Fakultas } \\
\text { Kesehatan }\end{array}$ & 750 & $50,8 \%$ \\
$\begin{array}{c}\text { Fakultas } \\
\text { Nonkesehatan } \\
\text { Total }\end{array}$ & 727 & $49,2 \%$ \\
\hline
\end{tabular}

Berdasarkan Tabel 3, dapat diketahui bahwa mahasiswa fakultas kesehatan memiliki total perilaku positif yang lebih besar dibandingkan dengan mahasiswa fakultas nonkesehatan. Dengan persentase perilaku positif pada mahasiswa 
fakultas kesehatan yaitu sebesar 50,8\%, sedangkan mahasiswa fakultas nonkesehatan memiliki persentase perilaku positif sebesar $49,2 \%$. Menurut Notoatmodjo (2003) perilaku dipengaruhi oleh 3 faktor utama, yaitu faktor-faktor predisposisi (salah satunya pengetahuan), faktor-faktor pemungkin (fasilitas) dan faktor-faktor penguat. Hal ini juga sejalan dengan pernyataan Sari (2006) menyatakan bahwa pengetahuan atau kognitif merupakan dominan yang sangat penting bagi terbentuknya perilaku, dan perilaku yang didasari pengetahuan akan bertahan lebih langgeng daripada perilaku yang tidak didasari pengetahuan. Perilaku Hidup Bersih dan Sehat (PHBS) dapat dipengaruhi oleh banyak faktor, diantaranya: umur, jenis kelamin, lingkungan, dan tingkat pengetahuan. Menurut Fardhiasih (2018), tingkat pengetahuan tidak dapat dijadikan tolak ukur mengenai perilaku hidup bersih dan sehat seseorang, namun hanya dapat dijadikan sebagai faktor risiko mengenai perilaku hidup bersih dan sehat. Pengetahuan yang dimiliki setiap orang dapat diperoleh secara internal maupun eksternal. Pengetahuan internal dapat diperoleh berdasarkan pengalaman yang dimiliki oleh setiap individu, sedangkan pengetahuan eksternal yaitu pengetahuan yang diperoleh dari orang lain maupun lingkungan (Restiasih, et al., 2017).

Nilai Asymp. Sig. (2-tailed) atau P Value = 0,403 menunjukkan bahwa tidak ada perbedaan yang bermakna antara perilaku mahasiswa fakultas kesehatan dengan mahasiswa fakultas nonkesehatan. Hasil penelitian sejalan dengan penelitian Fardhiasih (2018), tingkat pengetahuan seperti fakultas ataupun jurusan seseorang tidak dapat dijadikan faktor pembeda mengenai perilaku hidup bersih dan sehat yang dilakukan. Perbedaan tingkat pengetahuan hanya dapat digunakan sebagai faktor risiko terhadap perilaku hidup bersih dan sehat yang dilakukan, disamping itu, pengetahuan yang dimiliki seseorang tidak hanya diperoleh melalui pembelajaran formal. Pengetahuan yang dimiliki seseorang mengenai perilaku hidup bersih dan sehat juga bisa diperoleh melalui lingkungan sekitar ataupun hasil eksplorasi dari individu itu sendiri terlebih lagi pada era globalisasi seperti sekarang, dimana ilmu pengetahuan dapat diakses dengan mudah dan cepat.

Tabel 4. Perbandingan Total Skor Mahasiswa Kesehatan dan Nonkesehatan

\begin{tabular}{lcc}
\hline & $\begin{array}{c}\text { Median } \\
\text { (Minimum- } \\
\text { Maksimum) }\end{array}$ & Nilai P \\
\hline $\begin{array}{l}\text { Mahasiswa } \\
\text { Kesehatan (n=48) }\end{array}$ & $16(9-20)$ & 0,403
\end{tabular}

\begin{tabular}{lc}
\hline & $\begin{array}{c}\text { Median } \\
\text { (Minimum- } \\
\text { Maksimum) }\end{array}$ \\
\hline Mahasiswa & Nilai P \\
$\begin{array}{l}\text { Nonkesehatan } \\
(\mathrm{n}=48)\end{array}$ & $16(7-20)$ \\
\hline $\begin{array}{l}\text { Uji Mann-Whitney. } \\
\text { kesehatan 50,85; mahasiswa nonking mahasiswa }\end{array}$ \\
\hline
\end{tabular}

Tabel 5. Distribusi Rata-Rata Total Perilaku Positif Responden Berdasarkan Jenis Kelamin dan Usia

\begin{tabular}{|c|c|c|c|c|}
\hline & Karakteristik & & $\begin{array}{c}\text { Rata- } \\
\text { Rata } \\
\text { Perila- } \\
\text { ku } \\
\text { Positif }\end{array}$ & $\begin{array}{c}\text { Persen } \\
\text { tase }\end{array}$ \\
\hline \multirow{4}{*}{$\begin{array}{l}\text { Jenis } \\
\text { Kela } \\
\text { min }\end{array}$} & \multirow{2}{*}{$\begin{array}{l}\text { Fakultas } \\
\text { Kesehatan }\end{array}$} & $\begin{array}{l}\text { Laki- } \\
\text { laki }\end{array}$ & 14,13 & $23,60 \%$ \\
\hline & & $\begin{array}{l}\text { Perem- } \\
\text { puan }\end{array}$ & 15,93 & $\begin{array}{c}26,61 \\
\%\end{array}$ \\
\hline & \multirow{2}{*}{$\begin{array}{c}\text { Fakultas } \\
\text { Nonkeseha } \\
\text { tan }\end{array}$} & $\begin{array}{l}\text { Laki- } \\
\text { laki }\end{array}$ & 13,74 & $\begin{array}{c}22,95 \\
\%\end{array}$ \\
\hline & & $\begin{array}{l}\text { Peremp } \\
\text { uan }\end{array}$ & 16,07 & $\begin{array}{c}26,84 \\
\%\end{array}$ \\
\hline \multirow{16}{*}{ Usia } & \multirow{8}{*}{$\begin{array}{l}\text { Fakultas } \\
\text { Kesehatan }\end{array}$} & & 59,87 & $100 \%$ \\
\hline & & 18 & 15,75 & $9,12 \%$ \\
\hline & & 19 & 15,51 & $8,98 \%$ \\
\hline & & 20 & 16,10 & $9,32 \%$ \\
\hline & & 21 & 16,10 & $9,32 \%$ \\
\hline & & 22 & 15,00 & $8,68 \%$ \\
\hline & & 23 & - & - \\
\hline & & 24 & 18,00 & $10,42 \%$ \\
\hline & & 18 & 16,50 & $9,55 \%$ \\
\hline & & 19 & 15,10 & $8,73 \%$ \\
\hline & Fakultas & 20 & 15,20 & $8,80 \%$ \\
\hline & Nonkeseha & 21 & 15,00 & $8,68 \%$ \\
\hline & \multirow[t]{3}{*}{$\tan$} & 22 & 14,50 & $8,40 \%$ \\
\hline & & 23 & - & - \\
\hline & & 24 & . & 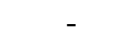 \\
\hline & Total & & 172,76 & $100 \%$ \\
\hline
\end{tabular}

Rata-rata total perilaku positif perempuan lebih besar dibandingkan rata-rata nilai total perilaku positif laki-laki. Uji Korelasi Pearson menunjukkan bahwa terdapat hubungan antara PHBS dengan jenis kelamin $(\mathrm{P}>0,001)$. Perbedaan jenis kelamin mungkin membentuk persepsi yang berbeda sehingga mempengaruhi sikap dan pengetahuan yang berbeda juga antara laki-laki dan perempuan (Suwaryo, 2017). Prince, (2020) menyatakan gender dan pendidikan merupakan determinan sosial penting dari kesehatan yang berdampak pada perilaku kesehatan. Perbedaan gender dan pendidikan berpengaruh pada perilaku menetap. Suen dkk (2019) menyatakan perempuan, paruh baya dan berpendidikan tinggi merupakan faktor pelindung untuk meningkatkan pengetahuan mencuci tangan 
yang benar. Kesalahpahaman terkait dengan konsep yang terkait dengan mencuci tangan sering terjadi di masyarakat. Diperlukan pendidikan tambahan menganai metode pengeringan tangan menunjukkan. Realita yang ada, perempuan memang lebih rajin, tekun, dan teliti ketika diberi tugas atau mengerjakan sesuatu (Suwaryo, 2017). Jenis kelamin merupakan faktor predisposing atau faktor pemudah seseorang untuk berperilaku.

Hasil penelitian tidak sejalan dengan yang dinyatakan dalam Fardhiasih, et al. (2018) bahwa tidak terdapat hubungan antara PHBS dengan jenis kelamin $(P=0,149)$. Menurut Sari (2016) dan Nurmalita (2016) laki-laki dan perempuan mempunyai andil yang sama dalam upaya meningkatkan kesehatannya dapat diterapkan dalam kehidupan sehari-hari melalui berperilaku hidup bersih dan sehat.

Usia dapat mempengaruhi pengetahuan, sikap, dan perilaku. Usia responden merupakan karakteristik responden yang membedakan tingkat kedewasaan responden. Selain itu juga menunjukkan tingkat pengetahuan atau wawasan responden. Dikatakan juga bahwa usia merupakan salah satu variabel demografis yang mempengaruhi persepsi dan pengetahuan seseorang. Usia yang lebih tua mempunyai pengalaman yang lebih baik sehingga kemungkinan tahu lebih banyak informasi (Notoadmojo, 2007).

Hasil uji korelasi Pearson dalam penelitian ini menunjukkan tidak ada hubungan antara usia dan PHBS pada fakultas kesehatan dan nonkesehatan $(P=0,763)$. Hasil penelitian ini, berbanding terbalik dengan penelitian Gita, et al. (2018) yang menyatakan bahwa tidak terdapat hubungan antara perilaku PHBS dengan umur $(\mathrm{P}<$ $0,001)$. Sempitnya rentang usia responden yang dilibatkan dalam penelitian kurang dapat menunjukkan pengaruh usia pada PHBS.Menurut Iskriyanti (2002), umur merupakan suatu faktor yang dapat menggambarkan kematangan fisik, psikis ataupun sosial sekurang-kurangnya berpengaruh dalam proses pembelajaran. Perubahan perilaku karena proses pendewasaan pada hakikatnya merupakan gabungan atau terjadi baik secara adaptif maupun naluriah. Melalui perjalanan umur yang semakin dewasa, makhluk yang bersangkutan akan melakukan adaptasi perilaku hidup terhadap lingkungannya, disamping secara alamiah juga berkembang perilaku yang sifatnya naluriah untuk melakukan praktik hidup sehat (Budioro, 1998).

\section{SIMPULAN}

Hasil penelitian menunjukkan tidak terdapat perbedaan PHBS pada mahasiswa fakultas kesehatan dan mahasiswa fakultas non kesehatan.

\section{UCAPAN TERIMA KASIH}

Penulis mengucapkan terimakasih yang sebesar-besarnya kepada responden yang telah membantu penelitian ini.

\section{DAFTAR PUSTAKA}

Budioro. (1998). Pengukur Pendidikan (Penyuluhan) Kesehatan Masyarakat. Semarang: Undip Press.

Fardhiasih, D.S., Suryani,D.,. (2018). FaktorFaktor yang Berhubungan dengan Perilaku Hidup Bersih dan Sehat ada Pedagang Angkringan di Kawasan Malioboro Yogyakarta. Jurnal Kesehatan Masyarakat, Vol. 3, No. 3.

Gita, et al. (2018). Faktor-Faktor yang Mempengaruhi Perilaku Hidup Bersih dan Sehat Pada Tatanan Rumah Tangga di Wilayah Kerja Puskesmas Poned X. Jurnal Sainmed, Vol. 14 No. 1 Juni 2018.

Iskriyanti, Hari. (2002). Hubungan Karakteristik, Pengetahuan dan Sikap Tentang PHBS dengan Praktek Kesehatan Keluarga dan Kesehatan Lingkungan di Kelurahan Rejowinangun Kecamatan Kota Gede Kota Yogyakarta Agustus 2002. Semarang: UNDIP.

Kemenkes RI. (2016). Perilaku Hidup Bersih dan Sehat (PHBS). Diakses pada tanggal 25 Mei

2020.

http://promkes.kemkes.go.id/phbs.

Kemenkes RI. (2020). Tanya Jawab Coronavirus Disease (COVID-19). Diakses pada tanggal $25 \quad$ Mei 2020. https://covid19.kemkes.go.id.

Notoatmodjo, S. (2003). Pendidikan dan perilaku kesehatan. Jakarta: rineka cipta, 16, 15-49.

Notoatmodjo, S. (2007). Promosi Kesehatan dan Ilmu Perilaku. Jakarta: Rineka Cipta. 
Nurmalita. (2016). Hubungan antara Jenis Kelamin, Tingkat Kelas, Pengetahuan, dan Sikap terhadap Perilaku Penggunaan Fasilitas MCK di SDN 01 Kecubung Mulya. Program Studi Keperawatan. STIK Sint Carolus. Jakarta.

Prince, S. A., Roberts, K. C., Melvin, A., Butler, G. P., \& Thompson, W. (2020). Gender and education differences in sedentary behaviour in Canada: an analysis of national cross-sectional surveys. BMC Public Health, 20(1), 1-17.

Roy, D., Tripathy, S., Kar, S. K., Sharma, N., Verma, S. K., \& Kaushal, V. (2020). Study of knowledge, attitude, anxiety \& perceived mental healthcare need in Indian population during COVID-19 pandemic. Asian Journal of Psychiatry, 102083.

Sari (2016). Faktor-Faktor yang Berhubungan dengan Perilaku Hidup Bersih dan Sehat sebagai Upaya untuk Pencegahan Penyakit Diare Pada Siswa di SDN Karangtowo Kecamatan Karangtengah Kabupaten Demak. Jurnal Kesehatan Masyarakat. Vol 4, No 3. Juli 2016 (Issn: 2356-3346).

Sari, S. (2006). Hubungan Faktor Predisposisi dengan Perilaku Higine Anak Jalanan Bimbingan Rumah Singgah YMS Bandung. Skripsi. Fakultas Ilmu Keperawatan Universitas Padjajaran. Bandung.
Sevilla, C. G. et. al. (1960). Research Methods. Quezon City: Rex Printing Company.

Suen, L. K., So, Z. Y., Yeung, S. K., Lo, K. Y., \& Lam, S. C. (2019). Epidemiological investigation on hand hygiene knowledge and behaviour: a cross-sectional study on gender disparity. BMC Public Health, 19(1), 401.

Susilo, dkk. (2020). Coronavirus Disease 2019: Tinjauan Literatur Terkini. Jurnal Penyakit Dalam Indonesia. Vol 7, No 1. Departemen Ilmu Penyakit Dalam Fakultas Kedokteran Universitas Indonesia - RSUPN dr. Cipto Mangunkusumo. Jakarta.

Suwaryo, dkk. (2017). Faktor-Faktor Yang Mempengaruhi Tingkat Pengetahuan Masyarakat dalam Mitigasi Bencana Alam Tanah Longsor. The 6th University Research Colloquium 2017: ISSN 24079189: 305-314.

World Health Organization. (2020). Coronavirus (COVID-19). Diakses pada tanggal $25 \mathrm{Mei}$ 2020. https://covid19.who.int/.

Yuliana. (2020). Corona Virus Diseases (COVID19). Wellness and Healthy Magazine. Fakultas Kedokteran Universitas Lampung. Vol 2, No 1, p. 187-192. 